\title{
ALGUNOS ELEMENTOS LEXICALES NO LATINOS EN EL IDIOMA ESPAÑOL
}

\author{
Manuel Antonio Quirós
}

\section{INTRODUCCION}

La historia de la lengua española también se ocupa del estudio de los elementos constituidos por el aporte no latino, o sea, de los elementos extranjeros o importados conocidos específicamente con el nombre de "préstamos". "The adoption of features which differ from those of the main tradition, is linguistic borrowing", escribe Bloomfield (1).

El español, como cualquier otra lengua, ha recibido en todas las épocas de su historia "préstamos lexicales" procedentes de otros idiomas romances o no romances, y en lo que respecta a los aportes del inglés en nuestros días no existe excepción alguna.

En este trabajo de carácter histórico-lingüístico sólo trataré una mínima parte sobre el "elemento lexical no latino en el idioma español", dado en todas las esferas del mismo, sobre todo en la léxico-semántica.

Las lenguas que le han proporcionado al español préstamos lexicales son históricamente: el ligur (¿anterior al ibero?), el ibero (¿autóctono de la Península Ibérica?), el vasco (una de las pocas lenguas no indoeuropeas aún existente), el etrusco (tan enigmático como el anterior y tampoco indoeuropeo), el fenicio el celta el griego, el hebreo, -con el cristianismo,- el germano, el árabe, (el superestrato más importante de la lengua española), el francés (langue d'oit), el occitano o provenzal (langue d'oc), el italiano, el portugués, el inglés, el catalán, el amerindio, (palabras procedentes del Nuevo Mundo), las voces dialectales y otras lenguas relacionadas con la sincronia de nuestro idioma que no serán tomadas en consideración en este trabajo.

El LATIN no es un préstamo lingüístico del español, pues le proporcionó a éste la base, esto es, el ESTRATO, por medio del latín vulgar o hablado; él es el ELEMENTO AUTOCTONO o NÁTIVO de las lenguas romances las cuales son el producto de transformaciones paulatinas pero sucesivas sufridas por el latín. De los cambios producidos en el idioma del Lacio a través del tiempo se ocupan la gramática histórica, la lingüística histórica y la lingüística románica diacrónica, si se toman las lenguas neolatinas conjuntamente.

El estrato latino penetró en las lenguas romances por obra de la romanización y latinización; éstas fueron emprendidas por 
los romanos en su afán conquistador. Por el primer término se entiende la adaptación de los pueblos anteriores a la llegada de los romanos a las costumbres de éstos; por el segundo, el aprendizaje del latín como segundo idioma. Ambas son el resultado de la imposición de colonos y aventureros romanos, de los matrimonios mixtos, de la labor realizada por los empleados de la administración pública romana, de la gente de comercio, y sobre todo, de la obra educativa emprendida por la escuela romana entre las clases dirigentes y de mayor rango y prestigio sociales de la "Hispania". Los romanos consiguieron los objetivos que se proponían: la explotación económica y la sumisión política y cultural, creando con ello una unidad muy envidiable por muchos estados hodiernos.

Tanto la romanización como la latinización de la "Hispania" fueron iniciadas en el año 218 a.C. n., cuando tuvo lugar el desembarco de los Escipiones en Ampurias; ambas concluyeron en el año 19 A.C. n., cuando Augusto logró pacificar a cántabros y astures y la "Hispania" pasa casi íntegramente a formar parte del Imperio Romano. A la gente indígena no le queda más que hablar el latín, por ser lengua de prestigio y para poder satisfacer sus necesidades diarias en el campo comercial y administrativo.

El latín de SUPERESTRATO es de penetración mucho más tardía, ya una vez formado el romance castellano, sin exclusión de las épocas posteriores a éste. Este latín recibe el nombre específico de "superestrato cultural latino" y es debido a la influencia del humanismo basado en parte en la tradición histórico-cultural que Roma ejerció en los campos del derecho, de la religión cristiano-romana, de la ciencia (terminología científica) y de la escuela en general; no es obra de ocupación territorial $\mathrm{n}$ de colonización político-militar o religiosa como la conquista árabe en suelo hispánico.

Caso típico de este superestrato son los neologismos modernos y las voces que suelen ser denominadas "cultismos", basados siempre en lenguas de cultura, para nuestro caso, en el latín y griego. Como ejemplos de cultismos en español están: radio, artículo, operario, digital, etc. Generalmente los cul- tismos han sido y son tomados del latín literario o clásico y aún del latín medieval,y casi siempre la palabra romántica culta se asemeja muchísimo a la forma latina correspondiente, pues la palabra neolatina no ha sufrido el proceso de desgaste como las voces populares. Como ejemplo de voces populares en español están: rayo, artejo, obrero, dedal, etc. Las palabras correspondientes latinas que originan los cultismos y voces populares anteriores son : $\operatorname{radiu}(m)$, articulu $(m)$, operariu $(m), y$ digitale $(m)$.

Resumiendo: se conoce con el nombre de PRESTAMO a las aportaciones dadas por las lenguas diferentes al latín y al superestrato cultural latino.

\section{CARACTEPISTICAS FONETICAS DEL DIALECTO CASTELLANO}

¿Cuáles son las innovaciones lexicales del "dialecto castellano" perpetuadas en el español? Pregunta de muy difícil contestación. El castellano es la continuación del latín en la región de los "castella" 'castillos', de aquí el nombre de Castilla, por lo tanto, su estrato es el mismo latín vulgar.

Los autores que escriben sobre esta materia se refieren a las innovaciones fonéticas propias del castellano, pero en ningún lugar a las lexicales, ¿no las hubo? .

Aunque esta monografía se refiera solamente a aspectos lexicales, voy a presentar de modo muy somero algunas características en el campo de la fonética castellana que se originaron en la Edad Media y que aún sobreviven. Ellas se propagaron en el siglo XII de Norte a Sur por obra de la Reconquista finalizada en el siglo XV con la toma de Granada, último reducto moro.

Fue el grupo central, también recconquistador del suelo hispánico que se encontraba en poder de los árabes, el que emprendió el avance desde Asturias y Castilla la Vieja. Por ser el de más ardor, valentía y empuje, desde el punto de vista político-militar y moral, el castellano logró imponer su dialecto, al extenderse luego por una gran parte de la Península Ibérica a expensas de los dialectos mozárabes; de ahí la extinsión de éstos. El castellano se hizo idioma español por una circunstancia política e histórica extra lingüistica. 
He aquí los fenómenos más importantes del castellano: la - $\underline{\text { ch- }}$ - española proviene del grupo latino - ct- (lacte da leche, factu da hecho). La propagación del cambio, $f-a b-$ de posible origen ibérico(formica de hormiga, formosu da hermoso). La palatalización de los grupos latinos iniciales pl-, cl-y fl- (pluvia da lluvia, clave da llave, flamma da llama). El grupo latino interno - cl- y -li- más vocal (convertido en español antiguo en 'ž' y que da en español moderno 'j' (ocyllu da ožo, luego ojo, muliere da mužer, luego mujer). La supresión de la $\mathrm{g}-\mathrm{y} \mathrm{j}-$ (yod) latinas iniciales ante e, $\mathrm{i}$ átonas - (ianuari da enero, germanu da hermano). La diptongación de e a ie y de o a ue -tónicas en sílaba libre o trabada (bene da bien, septe da siete, bonu da bueno, movet da mueve). El diptongo ai reducido a e (laicu da lego) y el de au que queda o (aurum da oro, taurum da toro).

Estas características fonéticas le dan al castellano y luego al español una fisionomía muy propia en el conjunto románico.

\section{3. ¿ES EL ESPAÑOL LENGUA PURA?}

No ha existido ni existe lengua alguna pura y aislada, al menos entre las lenguas de cultura (chino, sánscrito, griego, latín, árabe), y en caso de que existiera, no se podría establecer con respecto a qué se deban tomar los adjetivos "pura" y "aislada".

El mismo latín clásico en su supuesta pureza no es más que un producto híbrido formado de elementos autóctonos, dialectales, por ej. osco-umbros, y extranjeros como etruscos, celtas, griegos y mediterráneos. Las siguientes voces latinas son de este origen: "vinum" 'vino', "ficus" 'higo' y "laurus" 'laurel'.

Muy notable fue la influencia del griego sobre el latín. Como lengua de cultura, el idioma heleno transformó el latín de un idioma de campesinos que era ("egregiu", "rivalis", "versus", "putare", etc.) -términos netamente de origen rural- (2) en un idioma apto para la cultura superior ("philosophia", "poesia", "musica", schola", etc.). (3) -voces latinas típicamente culturales procedentes del idioma griego-Entonces el latín clásico no despreció ni tuvo en poco valor los extranjerismos.

Quizá algunos piensen que el idioma español o culquier otra lengua romance sea más "pura" y "autóctona" cuanto más se asemeje y acerque al latín; pero la supuesta pureza de éste no es otra cosa que una abstracción en desacuerdo con la realidad. Ya San Agustín observaba: “¿Qué quiere decir corrrección en el habla sino la observancia del uso hecho por otros y confirmada por la autoridad de quienes emplean la lengua antigua?" (4). Entonces para ser "correcto" habría que ser conservador, según W.D. Elcock (5). El latín literario o escrito, sinónimo de clásico, es en gran medida un producto de los gramáticos y literarios de un determinado período, pero el español se deriva en mayor escala del latín vulgar, no literario, sinónimo de hablado, de "la lengua de todos los días, que con desviaciones grandes o pequeñas de la lengua oficial escrita se habló en todos los tiempos, en todos los estratos sociales, en la vida de todos los días" (6). Además, la lengua latina usada en la Península Ibérica, con excepción de los arcaísmos y neologismos propios del latín vulgar de la misma, es una importación hecha por los romanos, potencia extranjera oriunda de la Italia, y no originario y creado en la Hispania; con todo, es el elemento "autóctono" del español.

Al latín llevado a la Hispania se incorporaron diversas características lingüísticas propias de los diferentes pueblos sometidos por Roma; éstos le dejaron voces al idioma latino las cuales constituyen el SUSTRATO lingüístico de la lengua española. Al llegar más tarde otros pueblos de diferente procedencia (germánica o semita) se encontraron con gran parte de la población romanizada y usando la lengua latina, pues los latinos ya se encontraban bien asentados en suelo hispánico. Los nuevos invasores no aniquilaron a la población romana, más tarde románica, ni política ni culturalmente; tampoco lo fue su idioma, el latín vulgar o romance en proceso de transformación, tal vez por razones de prestigio y de mayor cultura de parte de los 
subyugados; al contrario, tanto germanos como árabes respetaron ese latín en proceso cambiante, pero le dejaron al mismo muchisimas voces y características fonéticas y morfológicas (estas dos en mucho menor grado) conocidas con el nombre específico de SUPERESTRATO de la lengua española. Tampoco los romanos por prestigio cultural aniquilaron la cultura griega ni su idioma cuando efectuaron la conquista de la "Graecia".

\section{MEDIOS DE PENETRACION DE LOS PRESTAMOS}

¿Cuáles son algunos medios de penetración de los préstamos extranjeros en cualquier lengua? .

Saussure nos habla de la "fuerza de intercambio que crea las comunicaciones entre los hombres..." (7) y Bloomfield de "difusión cultural" (8).

Cuando un objeto no existente en un país o región es difundido, generalmente toma consigo la palabra correspondiente: los romanos no conocían la 'cerveza', la tomaron del galo con la palabra gala "cerevisia". Alemania produce exquisitos vinos, no conocidos aún por los antiguos germanos anteriores al siglo I en el cual llegaron los romanos a la "Germania" con el néctar de los dioses; con el vino iba también la palabra latina "vinum" que dio en alemán "Wein". Esta palabra alemana es pues un préstamo lexical latino. Tampoco los germanos tenían conocimiento de las excelentes calles construídas al estilo romano; los romanos les construyeron algunas "strata (via)" y del primer término procede el al. "Strasse" y el ingl. "street". Bloomfield designa el procedimiento anterior con la denominación de "Cultural borrowing" (9).

Los productos y sus voces respectivas llegados a Europa procedentes del Nuevo Mundo constituyen otro ejemplo de "préstamos culturales".

Las lenguas están sometidas a continuas relaciones debidas a las mismas que contraen los humanos. Por eso la imitación es algo intrínseco e inevitable entre nosotros los hombres, sea ella inteligente o no. La historia demuestra que todos los pueblos de una $u$ otra forma han imitado o imitan unos de otros; de esto no quedaron exceptuados los mismos griegos, a pesar de ser tenidos por el pueblo "creador" por excelencia en muchísimos campos de la cultura humanística. La cultura romana llegó a ser original y creadora por imitación de la griega.

El aprendizaje de una cultura nueva implica, sobre todo'al principio, toda una serie de imitaciones de los mayores las que nos permiten vivir como seres civilizados; caso típico de esto son los niños en el proceso de aprendizaje de su idioma materno: primero pasan por toda una serie de imitaciones hasta apropiarse del mismo. También las lenguas tienen mucho de imita. ción.

Los países que han logrado grandes invenciones en el campo técnico, por ej., los Estados Unidos y la Unión Soviética, ejercen una gran influencia técnica, económica, poli. tica y lingüística sobre los países en sus respectivas órbitas políticas; de ahí la tremenda y casi inevitable influencia del inglés estadounidense sobre el español de la América Hispana.

Otro medio de penetración de préstamos lo constituye el bilingüísmo. Por éste se introdujeron muchísimos términos de sustrato en el latín y posteriormente en sus lenguas continuadoras. Como ejemplo de bilingüismo de la Edad Media de España están los mozárabes, por quienes se trasmitieron del árabe al español elementos aló. glotos. (Los demás idiomas europeos recibieron los arabismos casi sólo por la influencia del español sobre ellos). El bilingüismo se ve muy favorecido por los matrimonios mixtos. No hay que olvidarse que los árabes habían llegado a la Península Ibérica sin mujeres.

Los conflictos bélicos suelen también favorecer la introducción de términos ex. tranjeros, pues en este caso se da, las más de las veces, una fuerte imposición lingüística en contra de los vencidos; como ejemplo está la ya mencionada romanización la cual supone un continuo estado de guerra contra los aborígenes, pueblos vencidos por los romanos.

Las traducciones permiten que se escapen términos del idioma traducido, máxime que hay muchas palabras intraducibles. Al latín medieval, que no es sinónimo de 
latín vulgar, penetraron muchas voces árabes pertenecientes al mundo de la ciencia, por ej. lat. med. "zephirum" dio en italiano 'zefiro', luego 'zefro', finalmente 'cero' en español; la palabra árabe es 'sifr".

Otra fuente también relacionada con los libros o con la lengua escrita son las abreviaciones de carácter internacional, por ej., UNESCO "United Nations Economic, Social and Cultural Organization". Dice W. Lehmann al respecto: "La lengua escrita ha llegado a ser una fuente tan importante de préstamos de esta clase que los nuevos nombres de las organizaciones suelen calcularse de antemano para que sus iniciales formen siglas apropiadas"' (10).

Finalmente, la vida moderna con todos los medios de comunicación existentes está muy favorecida y expuesta toda clase de préstamos, aunque por otro lado se encuentra el freno de la enseñanza escolar, siempre normativa y conservadora.

Existen bastantes causas más de préstamos, pero concluyo con la enumeración.

Soy de la opinión, con Bloomfield, que los préstamos no son algo pésimo que tenga que ser evitado y desterrado a toda costa, si todos aprendemos de nuestros vecinos por medio de la difusión cultural, practicas, ritos, creencias, manufacturas, técnicas, artes, hábitos y conductas ¿Y por qué tiene la lengua que ser exceptuada, siendo ella el principal vehículo de difusión? Los préstamos, lejos de evidenciar una pobreza en el idioma, lo enriquecen, porque con la palabra extranjera casi siempre se acompaña un producto nuevo y desconocido que enriquecerá nuestro patrimonio cultural, pues la cultura también está hecha de objetos materiales que ponen en claro la creación de un determinado pueblo.

Quiérase o no, la influencia extranjera, desde el punto de vista de la historia de las lenguas, ha sido y es inevitable. Para Sapir, "las lenguas, como las culturas, rara vez se bastan a sí mismas..." (11). Según W. Lehmann, "los préstamos son signos de difusión y enriquecimiento cultural..." (12).

En este sentido, se esté o no de acuerdo con la enseñanza del latín y el griego, se advierte que ellos han jugado $\mathrm{y}$ juegan un papel muy importante en calidad de idiomas prestatarios dado que son las lenguas básicas en la formación de los tecnicismos modernos, no sólo de las lenguas romances y germánicas sino en todas las lenguas culturales del mundo, pues la ciencia occidental es mundial.

\section{CLASES DE PRESTAMOS}

Debemos hacer las siguientes distinciones entre "Lehnwörter", "Fremdwörter",

"Bedürfnislehnwörter" y "Luxuslehnwörter", con la terminología en alemán (13).

Con el término "Lehnwörter" se entienden los préstamos incorporados completamente en el idioma receptor, de modo que no nos damos cuenta de que son palabras extranjeras, dado que reproducen los fonemas del idioma prestatario adaptados a la idiosincrasia de aquél, por ej., la palabra española 'brindis', que significa la acción de beber a la salud de alguien, es una alteración del alemán "ich bringe dir sie" "yo te la traigo' esto es, 'yo te traigo la salud', en donde la forma española no tiene casi nada del idioma originario.

Los "Fremdwörter, en cambio, conservan el aspecto formal de la lengua de origen extranjero y aunque sean muy usadas por los hablantes, estos mismos las consideran como formas extranjeras y casi siempre son condenadas por los puristas de los respectivos idiomas y no son vistas con agrado por parte de los académicos de la lengua; casi siempre la forma externa se asemeja a la del idioma prestatario; de ellas tenemos: "football", "golf", "tennis", etc., que son palabras deportivas del inglés del siglo XIX, "wagon", "tunnel", "ticket", términos ferroviarios; "whisky", "gin", "brandy", términos de bebidas alcohólicas.

Los Bedürfnislehnwörter son los préstamos obligados que designan objetos, costumbres o sentimientos característicos del país de origen y para los cuales no existen o no se han creado voces en el idioma receptor; pero si la palabra existe y aún así se importa la extranjera, entonces el préstamo se llama "Luxuslehnwörter", como la palabra "referee" de uso corriente en la terminología deportiva del español, para la cual éste posee 'árbitro' y 'juez'. 


\section{EL HECHO HISTORICO-LIN- GUISTICO}

Lo siguiente es una brevísima exposición sobre algunas palabras extranjeras en el idioma español; son elementos no latinos, $\mathrm{y}$ aunque tengan una carta de nacionalidad y se encuentren adaptadas al mismo, pues son "idioma español", en su origen fueron préstamos o extranjerismos. Son los préstamos nuevos o más recientes los tenidos como algo indebido, como en su época fueron quizá vistos los otros. Así sucede en la actualidad con los del idioma inglés.

¿Qué nos proporcionaron nuestros substratos, adstratos y superestratos?. He aquí unos ejemplos tomados de varias lenguas prestatarias en un plano diacrónico o histórico:

\section{a. Préstamos del Liqur}

Existió en la Península Ibérica una población de procedencia centroeuropea, análoga a la ligur, de origen mediterráneo, pero de lengua bastante indoeuropeizada; a tal población se le debe la voz 'páramo', documentada en tiempos de Adriano en una inscripción votiva de un ara de Diana hallada en León, en la que Tulio ofrece a la diosa la cornamenta de los ciervos que cazó (quos vicit) en la llanura del 'páramo' (in parami aequore). La voz significa 'meseta desierta'.

\section{b. Préstamos del Ibero}

Cuando los romanos pisaron tierra ibérica encontraron diferentes pueblos: turdetanos o tartesios, túrdulos, iberos, celtíberos, lusitanos y pueblos montañeses. Los iberos, los más conocidos, estaban compuestos de los bastetanos, edetanos, indigetes e ilegertes y otros más.

Palabras de procedencia de los iberos son: 'vega', de "vaika", de "vai" = 'rio' más el sufijo - ka, 'región del río'. La forma que precede a 'arroyo', "arrugia" es también ibérica con el significado de "conducto subterráneo'.

A continuación doy la etimología de uno de los dos nombres con que es designada la Península Ibérica: IBERIA, aunque no sea un préstamo del ibero sino del griego. Ella se encuentra registrada desde el siglo VI o V A.C. n. Procede del nombre del río 'Iber' (no el actual Ebro) sino de otro río al sur, cerca de la provincia de Huelva; de aquí designaron los griegos a los habitantes de la Península o sea los "Iberi", gr." I $\beta \eta \rho \in \varsigma$ de quienes se discute si son o no autóctonos de la Península Ibérica.

\section{c. Préstamos del Fenicio}

Los fenicios, pueblo semita, realizaron muchos recorridos por las costas del Mediterráneo; de hecho mantenían comercio con los pueblos costeros. No hay que olvidar la gran importancia que tuvieron los semitas en la historia del alfabeto, y que el fenicio fue el más importante, porque de éste se originó el alfabeto griego que a su vez dio origen al latino por intermedio de los etruscos.

El alfabeto latino ha perdurado hasta nuestro días y ha constituido un gran avance en la civilización.

El otro nombre con que es designada la Península Ibérica es HISPANIA. Parece que el nombre (latino) de "Hispania" sea fenicio o púnico. Se encuentra ya documentado desde el 200 a. C. n. y procede de I-SEPHA-IM: de la raíz "i" 'costa' o 'isla' más "se" o "saphan" 'conejo'. Otros son de la opinión de que procede de otra raíz anterior: 'span' o del hebrero "saphan", 'escondite', en el sentido de 'Tierra remota'.

Con el nombre de HISPANIA solían designar los romanos a la IBERIA, por eso Estrabón en el siglo I decía: "IBERIA = HISPANIA". Los cartagineses fueron los intermediarios en el paso del nombre al latín.

\section{d. Préstamos del Vasco}

Sin prestar atención al problema del origen del pueblo vasco y a sus posibles relaciones con el ibero, problema aún no resuelto, es muy normal que el vasco por vecindad geográfica (adstrato) le haya prestado algunas palabras al español; hago sólo mención de la voz 'izquierdo', procedente del vasco "ezquer", voz que sustituyó a la latina "sinister" tal vez por el mal agüero que poseía esta palabra en la Edad Media; un resto de su significado lo tenemos aún en español moderno en 'siniestro'. 
e.

\section{Préstamos del Etrusco}

El etrusco ("rasna" o "rasenna" en su idioma; "tirrenos" o "tirsenos" entre los griegos, y "etrusci", que da "Etruria" o "tusci", que da Toscana, entre los latinos) constituye un sustrato del latín de la Península Itálica y es natural que su influencia haya sido aquí más preponderante; con el mismo latín irían algunas palabras etruscas hacia la Península Ibérica y por eso han pasado al español.

Ya se habló de la importancia de los etruscos como intermediarios en la transmisión del alfabeto del griego al itálico y por consiguiente al latín.

E1 estrusco desapareció completamente unos siglos después de la conquista romana; la poco resistencia que puso fue sólo debida a la fuerza de su cultura; también desapareció su lengua, de la cual quedaron únicamente nombres de sustrato, como por ejemplo "César"; según unas glosas griegas y latinas, este sustantivo significa 'dios'; Esiquio escribe en una glosa: "aisoi, theoi hypò Tyrrenon", esto es, "aisoi", que significa "dioses entre los etrus-

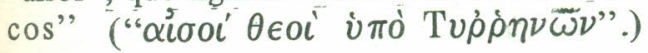

También Suetonio dice que el nombre de "aisar" debe de significar 'dioses' (14).

La palabra española 'persona' viene del homónimo latino "persona"; éste viene del etrusco en donde al sufijo "-ona" ha sido añadido "fersu", deformación del griego " $\pi \rho \sigma \sigma \omega \pi \sigma \nu "$.

La voz persona'es un término salido del teatro; en un principio significaba 'cara', luego 'máscara' (del actor), después llegó a significar el 'personaje en el drama' y por último adquirió el significado de 'individuo', 'persona'.

Todas las lenguas romances, exc. el rumano, siguen la forma latina.

\section{f. Préstamos del Osco-umbro}

El osco-umbro, o el osco y el umbro, son dialectos propios de la Península Itálica, esto es, del itálico común. Junto con el latino-falisco constituyen el elemento indoeuropeo de la Italia. También los dialectos han tenido influencias sobre el latín; como ejemplo de éstos, y transmitidos a las lenguas neolatinas, tenemos: "bos", 'buey', probablemente "lupus", 'lobo', "furnus", 'horno', 'furca”, 'horca', etc.

\section{g. Préstamos del Celta}

Poseen los celtas más relación con la "Gallia" (Francia) que con la "Hispania" (España). Su lengua indoeuropea afín al latín, por ej. celta "rix", lat. "rex", 'rey', es el principal sustrato del francés.

Procedentes de la "Germania" (Alemania), invadieron la Galia hacia el 500 a.C., pero también penetraron en la "Hispania" y le legaron indirectamente al idioma español algunas voces: junto con "cerevisia", "cerveza', ya nombrada, una de las más conocidad es 'carro', latinizada en "carrus" que significa 'carro' (de 4 ruedas), mientras "carpentum", también palabra celta, significa 'carro' (pero de 2 ruedas). De "carpentum" se deriva "carpintero. "Carrus" es el carro de lucha de los jefes galos y ha tenido mucho uso en el mundo románico.

Otro celtismo es el verbo "cambiare" que sustituyó al latino "mutare". Dice Corominas: "El latín "cambiare" se encuentra en Apuleyo y en otros autores del S. II d. C. n., es un préstamo del galo, que penetró en el sentido comercial de 'trocar', logró afian. zarse gracias a la plétora semántica del latino castizo "mutare", y en la época romance ganó terreno frente a éste en todas sus acepciones, dejándole relegado a unos pocos usos especiales en todas las lenguas hermanas, salvo el rumano (15); Iorgu Iordán dice: "Es muy elocuente el verbo "cambiare" 'cambiar' que indica un desarrollo comercial y unas prácticas nada desdeñables (16).

\section{h. Préstamos del Griego}

La cultura griega influyó en la latina en casi todos los aspectos, y lo que más interesa, por medio de la cultura latina en el mundo moderno tanto occidental como oriental. En este contexto no es de extrañar que las lenguas romances posean una gran abundancia de términos prestados del griego, pertenecientes muchísimos de ellos a la categoría del espíritu, de las ideas y de los niveles superiores de la lengua.

El léxico griego, uno de los más ricos y abundantes en la historia de las lenguas, ha 
penetrado en la cultura románica por varias vías: por medio del latín clásico, del latín vulgar, del latín medieval, del cristianismo, del árabe (Escuela de Traductores de Toledo) y de los neologismos modernos tomados del griego desde el Renacimiento italiano hasta nuestros días, en los que se encuentran incluidas casi todas las voces de la terminología de la técnica y ciencias modernas (en el sentido más amplio de la palabra). Siempre me ha llamado mucho la atención cómo la ciencia moderna usa palabras para expresar objetos que los griegos mismos no conocían, como 'teléfono', 'telégrafo', 'fotografía', 'termómetro', 'helicóptero', 'discoteca', 'telescopio', 'microscopio', ‘dinamo'. Los mismos nombres de las ciencias exactas, como física, 'química' y hasta los más recientes relacionados con el espacio interestelar tales como 'astronauta' y 'cosmonauta', etc. etc., hablan por sí solos de la gran importancia del griego en los estudios lingüísticos. Aquí sobran las palabras en defensa del griego, aún en contra de muchos que estudian "res naturalia" y los cuales en cada momento hacen uso de voces griegas. Me atrevo a hacer esta afirmación: "el español es latín y griego, a no ser que no se le dé importancia a la cultura, entonces es casi sólo latino.

Se dice que la mayor influencia después de la latina, es la árabe, pero esa afirmación vale para la cantidad y no para la calidad, pues nuestro mundo cultural y nuestra manera de enfocar la vida es más helénica que árabe.

Un préstamo griego de origen remoto y de tanta fortuna en la técnica mundial es la palabra 'máquina'; todas las lenguas modernas europeas la derivan del latín "machina"; en griego es $\mu \bar{\alpha} \chi \alpha \nu \alpha$, en donde la primera alfa indica influencia del dialecto dórico; pero lo interesante es que la voz derivada correspondiente a la persona que repara las máquinas, el 'mecánico', sea de esta forma con /ē/ y no 'macánico'. ¿A qué sabe el cambio de $/ \bar{a} /$ á $/ \bar{e} /$ en todas las lenguas romances, en inglés, alemán, ruso y en muchísimas otras?. Esta /e/ procede del dialecto jónico, y no del ático, $\mu \eta \chi \alpha \nu$ แKó , , lat., "mechanicus".

Algunas voces griegas penetradas por vía popular en el léxico español y románico son: $\theta \epsilon \tilde{\imath} о \varsigma$, 'tío'; la voz latina "avun- culus" no dio ninguna derivación ni en español ni en italiano, pero en francés dio

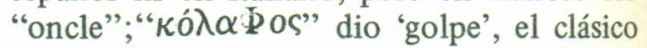
'ictus' desapareció; " $\pi \dot{\epsilon} \tau \rho \alpha$ " dio "piedra', las formas latinas "saxum" y "lapis" no dieron formas romances; " $\zeta \tilde{\eta} \lambda o s "$ dio 'celo', pero "studium" con el significado de 'celo' desapareció. ¿No es digno de ser notado el hecho de que el griego haya sustituido las palabras latinas anteriores en las lenguas romances? .

La influencia de un idioma sobre otro no sólo se da exteriormente en el cuerpo total de la palabra, sino que a veces se dan los préstamos semánticos o de significado: son términos de contextura latina pero de contenido griego. La lengua de los gramáticos, filósofos y teólogos posee muchos de esos términos comprensibles, en una cultura como la griega que había creado mucho en esos campos, no así la latina. Estos préstamos se llaman PRESTAMOS DE TRADUCCION o CALCOS.

Muchas palabras del cristianismo son calcos semánticos del griego o del hebreo; por ej. la palabra hebrea "ml'k" 'mensajero' a menudo se usó en el sentido de 'ángel'. Como en el griego no había ninguna palabra para designar 'ángel', los traductores de la Biblia copiaron la polisemia del término hebreo empleando el griego “ ‘á $\gamma \gamma \epsilon \lambda$ s $^{\circ}$ 'mensajero' con el significado de 'ángel' (17).

\section{i. Préstamo del Hebreo y del Cris- tianismo}

El Cristianismo es una religión originada en un medio judío-helenístico que jerció una gran influencia en el idioma español y en las nacientes lenguas romances, pues sus textos sagrados estaban escritos en hebreo, arameo y griego, lengua ecuménica de la cristiandad por más de 100 años.

La predicación cristiana en occidente fue inicialmente obra de orientales helenizados y de griegos. La penetración de la Buena Nueva en las regiones mediterráneas occidentales comenzó en aquellos núcleos de griegos y de orientales helenizados, los cuales eran muy numerosos en la plebe urbana. En la misma Roma, la lengua oficial de la iglesia primitiva fue el griego: en este idioma se encuentra escrita la Epístola a los Romanos 
del Apostol Pablo. El paso del griego al latín como idioma de la iglesia -al cual dio desisivo impulso, según parece, el Papa Víctor I (189-198 ca.), de origen africano -se efectuó lentamente hacia la mitad del siglo II en textos de apostolado, hacia la mitad del III en documentos episcopales y hacia la mitad del IV en la liturgia. Es por consiguiente natural que un filón conspicuo de neologismo lexicales y fraseológicos introducidos en el latín por medio del cristianismo esté constituido por orientalismos, no muchos semitismos y muchísimos grecismos; lo interesante es que todos estos términos hayan pasado al español y que inclusive por el cristianismo de nuestro pueblo tengan vigencia aún hoy.

"Palabra" procede del latín cristiano "parabola", prestada por el griego

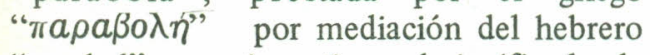
"paschal"; en griego tiene el significado de 'comparación' y luego de 'parábola', esto es, 'palabra' (la de Jesús) pues tanto para la iglesia de los primeros tiempos como para los primeros cristianos, la palabra de Jesucristo era la 'palabra' por excelencia; de ahí la confusión semántica originada por mediación del hebreo. Jesucristo solía hablar en 'parábolas'; las 'parábolas' de él eran "parábolas" (las palabras) por excelencia.

"Shabbat", gr. $\sigma a ́ \beta \beta a \tau o \nu$, es un préstamo de origen hebreo pasado al latín por intermedio del griego. De la palabra latina "sabbatu", se origina el español 'sábado'. Los demás días de la semana son de origen latino-pagano: Lunae dies, Martis dies, Mercurii dies, Iovis dies y Veneris dies. Unicamente 'domingo' es de origen cristiano, por ser el 'Día del Señor', esto es: "dies dominicus" adj. éste procedente del lat. "dominus", 'señor'.

Otros préstamos griegos en el latín cristiano son los referentes a la organización jerárquica o eclesiástica; por ejemplo, la palabra con que es designado el máximo jefe de la Iglesia Católica, el 'Papa', que viene del griego " "лémaş" con el significado de 'obispo' (s. III), en latín desde el siglo VI, 'Obispo de Roma' y desde el IX, 'el más alto en la jerarquía eclesiástica', lo que se explica por la centralización de la iglesia durante su historia a imitación de la jerarquía del Imperio Romano. Corominas dice que la voz
'Papa' es un término de respeto con que uno se dirige a los eclesiásticos, propiamente 'papá', voz expresiva de creación infantil (18).

\section{j. Préstamos del Germano}

De los pueblos germanos que más directamente tuvieron que ver con la lengua española, se encuentran los visigodos o godos de occidente. Estos ocuparon la "Hispania" durante unos 300 años, período que coincide con la formación de un "romance hispano primitivo", época bastante desconocida desde el punto de vista lingüístico.

La capital del reino visigodo era Toledo; pero al contrario de lo que se podría esperar, no tuvieron los visigodos ninguna influencia preponderante en el incipiente español ya que era una colonia minoritaria de unos 200.000 individuos ya parcialmente romanizados, por haber vivido anteriormente en contacto con los romanos en calidad de aliados o de enemigos del Imperio Romano en Dacia, Mesia, Italia y Galia; por eso fue que "Hispania" no pasó a llamarse "Gotia" como "Gallia" pasó a denominarse "Frantia" (por los francos). Incluso abandonaron su propio idioma y aceptaron el romance al fundirse con el elemento latinizado.

En la literatura sí tuvieron importancia, pues le dieron a "Hispania" la inspiración épica manifestada en la epopeya castellana.

El reino visigodo tuvo su fin con la llegada de los árabes a suelo hispano en el 711 d.C.n.

La onomástica española he heredado de los godos nombres de origen visigodo de mucho uso. Casi todos ellos están relacionados con el valor guerrero, muy propio de los pueblos germánicos: "all", 'todo' y "wars" 'preferido' dieron el nombre de 'Alvaro'; “frithu” ( alemán "Friede”) 'paz' y "nanth" 'atrevido' dieron "Friedenandus", luego "Ferdinandus" y 'Fernando'; "hroths" 'fama' y “riks" 'poderoso' orginaron “Rodericus”, esp. 'Rodrigo' (19).

Aunque el patronímico español en "-ez" (Rodríguez, Fernández, Ramírez, etc.) sea de influencia ligur (probablemente) y haya sido incorporado al idioma vasco con 
el valor de posesivo, sin embargo, su difusión fue debida al visigodo por sus muchos genitivos góticos latinizados en "-rici-" que dio '-riz-rez' ("Roderici” da 'Rodríguez', esto es, 'hijo de Rodrigo') pospuesto al nombre con el fin de indicar el apellido paterno (20).

En general, el escaso centenar de palabras germánicas en español es de introducción anterior a la llegada de los visigodos a tierra ibérica. Los préstamos germanos de penetración tardía se introducen en España por medio del francés y del provenzal, siendo la mayor parte de ellas de tipo militar.

De origen germana e incorporada en el francón es 'jardín' que sustituyó la forma latina "hortus". En francón "*gard(o)" significa 'recinto'; esta palabra pasó al antiguo francés "jart" de donde procede el francés moderno "jardin". La difusión de este término fue llevada a cabo en las demás lenguas romances por medio del francés, pues la palatalización indica el paso del galo-romance, a los demás idiomas neolatinos.

La palabra 'jardín' es panrrománica y por lo tanto muy parecida en las lenguas romances; no hay que creer o postular en estos casos un origen necesariamente latino. El método comparativo deberá de proceder con cautela en estos casos.

Algunos término latinos han sido sustituidos por palabras germánicas: "blank" sustituyó a "albus", de ahí 'blanco' en español, "riks" dio 'rico' al sustituir la palabra latina "dives", "busk" originó "bosque'; la palabra latina "silva" (en esp. 'selva' es algo diferente de bosque) desapareció. La palabra germánica "busk" corresponde al alemán actual "Busch".

\section{k. Préstamos del Francés}

Se conocen con el nombre de galicismos los préstamos directos del francés (langue - d'oi1) cuya influencia sobre el español ha sido muy grande desde la Edad Media, desplazada en la actualidad únicamente por la del inglés.

Por ser los galicismos bastante conocidos, sólo insistiré en una palabra de mucho uso: burocracia, o sea el poder o la influencia de los empleados públicos que trabajan en las oficinas (bureaux) gubernamentales.

La palabra en español ha sido tomada del francés en cuya lengua es hibrido, esto es, formada por un elemento griego y otro latino. Para la explicación etimológica me baso sobre todo en los Origenes de las lenguas neolatinas de Carlo Tagliavini (21).

Burocracia fue creada en Francia por el economista Gournay (1712-1759) sobre el modelo de 'aristocracia', 'democracia', etc. y en este sentido es más bien un neologismo culto. En francés se encuentra documentada en el siglo XIV, uniendo "bureau" 'oficina' a

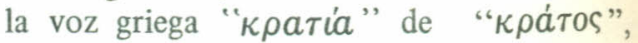
"poder. Limitada durante algunas décadas al medio de los economistas, la palabra se hizo popular durante la Revolución Francesa y luego fue acogida por la Academia Francesa en 1798; de Francia pasó a todas las otras lenguas romances.

"Bureau", con el sentido de 'oficina' se desarrolló en el s.VII a partir de "bureau" 'escritorio', y éste a su vez, del sentido primitivo de 'paño buriel' especialmente para cubrir mesas y escritorios. La voz se hace remontar a un latín popular "bura", existente también en español y portugués: “*bura”, 'tela de lana' que es una variante de "burra" 'lana bruta'. La penetración en el idioma español data de 1832-1836.

\section{Préstamos del Arabe}

El idioma árabe constituye el más importante SUPERESTRATO del español con más o menos unas 4.000 palabras.

Con la llegada de Tariq, general árabe y de sus 10.000 seguidores el 19-26 de julio del 711 d.C. n., la Hispania visigoda cambia de panorama y de dueño.

Traían los árabes consigo una unidad religiosa y lingüística y sobre todo un gran ardor religioso lleno de fanatismo el cual los impulsaba a la "Guerra Santa". También traían una gran civilización que había adoptado numerosos elementos griegos y orientales; de los primeros recogen su filosofía; de los segundos, las matemáticas de la India.

Esta nueva raza de origen semita va a dominar la Península Ibérica hasta 1492, fecha triplemente grandiosa para España, $1^{\circ}$ por la expulsión de los moris, $2 \mathrm{O}$ por el descubrimiento de América y $3^{\circ}$ porque Elio 
Antonio Martínez de Cala, llamado Antonio de Nebrija o de Lebrija (de su pueblo natal en la provincia de Sevilla) escribe la primera gramática de las lenguas modernas, su famosa GRAMATICA CASTELLANA.

El árabe se impuso como principal superestrato del español sobre todo por el bilingüismo que se dio entre los MOZARABES. Eran éstos, del árabe "musta' rab", 'arabizado', cristianos de usos y costumbres árabes. Su número era particularmente grande en el sur. Muchísimos seguían usando el romance con gran influencia del elemento árabe en su vida familiar, pero éste era usado como lengua de cultura. Más aún, la Hispania mozárabe era tetralingüe: el árabe clásico es el idioma de los documentos y actas oficiales, de la literatura y del culto; el árabe vulgar, es ef dialecto andaluz o el mozárabe, lengua de conversación; el latín medieval es el idioma literario de los mozárabes y el romance hispánico es la lengua familiar de los cristianos mozárabes. Esta mezcla de idiomas se dio sobre todo entre los enaciados quienes eran los mandaderos y correos, por esto mismo, rufianes y espías.

Llama la atención el hecho que los árabes no se romanizaran como lo habían hecho anteriormente los visigodos ni que los románicos se arabizaran del todo. La respuesta más verosímil es el factor religioso.

Como dije antes, el mozárabe dejó de existir en la misma Edad Media, pues con la misma reconquista del suelo hispánico iba la del dilaecto derivado del latín, el CASTELLANO, pronto a convertirse en lengua española.

Préstamos españoles tomados del árabe y de origen erudito son, entre otros: 'álgebra', 'logaritmo', 'azimut', 'almanaque', 'alquimia', 'elixir', etc. etc., aquí sólo me detendré en álgebra, alquimia y elixir para los cuales sigo a Tagliavini (22), pero conviene recordar que fue precisamente en ese medio híbrido arábigo-romance en que nacieron dos tipos de composiciones también híbridas: el zéjel y las jarchas que se encuentran en los inicios mismos de la literatura hispánica y hasta románica; en efecto, las teorías más modernas no ponen más a los poetas trovadores del sur de Francia con Guillermo IX de Poitiers a la cabeza, el primer trovador conocido, como a los inicia- dores de las literaturas románicas.

'Alquimia' está atestiguada desde el siglo XIII; procede del árabe "al-k̄̄-mīyā", del griego bizantino " $\chi v \mu \epsilon i a$ " 'fusión'. $\mathrm{Su}$ sentido era el de piedra filosofal para transformar los metales no nobles en oro. En árabe el nombre común de la piedra filosofal era "el-iksïr", del griego " $\eta \rho o ́ v "$ ", de donde procede en español 'elixir' con el sentido general de 'remedio maravilloso' o 'licor mágico'.

También la voz científica 'álgebra' es de origen erudito; proviene del árabe “al-gabr", 'restauración', 'reducción'. En 1202 Leonardo Fibonacci, matemático de Pisa, reveló al mundo occidental el álgebra árabe en su "Liber Abbaci". El nombre de álgebra procede del título "al Kitāb al muhtasar fĩ hisāb AL- Ǧ ABR wa-1-muqäbala", esto es, "ciencia de las reducciones y comparaciones, escrito por el matemático Muhammad ibn Mũsà al-Hwärzmī. Eşte nombre contaminado con

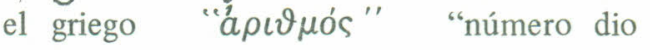
'algoritmo", de donde 'logaritmo'.

\section{m. Préstamos del Occitano}

Los occitanismos son las influencias o préstamos del provenzal antiguo o langue d'oc. La influencia occitana quedó sólo limitada a la Edad Media y proporcionó únicamente préstamos de carácter lexical.

El provenzal, la lengua de los poetas trovadores fue relegado a un simple dialecto del francés actual desde la famosa Cruzada contra los Albigenses; actualmente su uso es cada vez más restringido; pero antes de dicha cruzada fue la lengua romance más latina, la "linga romana" por excelencia, debido sobre todo a la rica literatura creada en el campo de la lírica casi exclusivamente sobre el amor cortés y la casuística amorosa. En esta lengua cantaron en la Edad Media en éxtasis amoroso los poetas trovadores, entre los que sobresale BERNARD DE VENTADORN.

Entonces las influencias del provenzal están casi limitadas a palabras de la vida refinada del ambiente cortesano y trovadoresco,tales como 'cuita', 'desdén', 'gayo', 'solaz', 'prez', 'bello' 'vergel', 'ruiseñor', y a la técnica formal de esa gran poesía, como 
'flauta', 'son', 'bailar', etc.

En este trabajo me limitaré sólo a dos palabras prestadas por el provenzal antiguo: 'ruiseñor' y 'trovador'.

La primera ha tenido empleo en la poesía trovadoresca; dice Bernats de Ventadorn en una de sus famosas canciones. "Pel doutz chan que. 1 rossinhols fai

la noih can me sui adormitz..."

La forma latina de la palabra subrayada es "luscinia" o "luscinius", cuyo diminutivo es "lusciniolus" en donde la primera " 1 " se cambia en " $r$ " por disimilación; queda "rusciniolus"; también se cree que haya un cruce con "russus" 'rojo', por el color del animal. La palabra española ha tenido una influencia de etimología popular del nombre 'Ruy' (Rodrigo) más señor ("el rru señor, que es un buen jogral..."), Elena y María, s.XIII.

Otra palabra muy típica occitana es 'trovador', el poeta que hacía poesía en 'langue d'oc' o provenzal; el sustantivo se deriva del verbo provenzal "trobar".

Para esclarecer esta etimología se han ocupado muchos eximios romanistas, tales como: Schuchardt, Gastón París, Fr. Diez, E. Gammillscheg, Bloch-Wartburg y Leo Spitzer. Lo esencial de la discusión consiste en averiguar si la palabra viene del latín "turbare", esto es, "enturbiar" y "envenenar el agua con torvisco y plantas semejantes al objeto de pescar', de donde 'pescar' y luego 'encontrar'; o si viene del latín popular "tropare", derivación de "tropus" "figura retórica' y en la Baja Epoca en el lenguaje de la música 'inventar un aire' de donde 'componer' (un poema), luego 'inventar', 'descubrir'. El sentido de 'componer' ha sido muy usado en al Edad Media en la lengua literaria, el cual corresponde al empleado en provenzal antiguo.

\section{n. Préstamos del Italiano}

Según Ramón Menéndez Pidal, después del francés fue el italiano el que más enriqueció al español por la cultura superior del renacimiento y por la dominación española en Italia (23).

No basta saber mucho de música para darse cuenta cómo casi toda, por no decir toda, la terminología de la música culta europea es de origen italiano. $\mathrm{Si}$ observamos una partitura musical $\mathrm{u}$ oímos a un director de orquesta de habla no española ensayar la partitura de una sinfonía o concierto, él se dirigirá a los músicos de su orquesta sinfónica probablemente en inglés, pero usará toda la terminología musical en italiano; de hecho, Italia ha contribuido muy notablemente al nacimiento, desarrollo y florecimiento de las artes. Ella posee grandes maestros de la música y los más famosos violines e instrumentos de cuerda vieron la luz en esta nación amante de las cosas bellas.

También el 'piano', uno de los instrumentos musicales con mayor éxito en el mundo de la música, está muy ligado en sus inicios históricos con Italia. ¿Qué significa 'piano? .

En italiano es un adjetivo derivado del latín "planus" y quiere decir 'suave', 'en voz baja'; es una reducción de "piano e forte": 'suave y fuerte' o de "forte e piano". "Pianoforte" es la palabra que comúnmente se usa en italiano actual. El 'piano', en contraposición con el clavicordio y el cémbalo, sus predecesores, da los 'fuertes' y los 'suaves', sacando de él la música moderna sobre todo a partir de Beethoven, por gradación de la fuerza, efectos dinámicos productores de hermosos matices de belleza.

Es pues el 'piano' una especie de clavicordio con "crescendi". El 'piano de martillos' (el "Hammerklavier" beethoveniano), precursor directo de nuestro actual piano, fue inventado en Florencia en el año de 1709 por BARTOLOMEO CRISTOFORI, Gravicembalo col piano e forte 'un cembalo grave para producir notas débiles y fuertes'.

\section{o. Préstamos del Portugués}

Con respecto al portugués se debería esperar más influencias en el español por la cercanía de España con Portugal, por la influencia de la lírica de los poetas gallego-portugueses en la Edad Media y porque hubo muchos escritores portugueses que escribieron en español y viceversa; pero quizá el mismo parecido de las dos lenguas impidió la penetración de más lusitanismos en el español.

De origen portugués son: 'mermelada', 'macho', 'arisco', 'capullo', 'faena', 'chuvasco' y la expresión 'hechar de menos', en 
port. "achar menos".

'Carabela' es un diminutivo del latín tardío "carabus", 'embarcación de mimbres forrada de cuero', en griego es "кá $\rho а \beta о$ s" 'cangrejo' de mar' y 'embarcación'. La forma portuguesa es "caravela". En todo el s.XV la "carabela" fue considerada en toda Europa como un navío típico de origen portugués. No hay que olvidar que Cirstóbal Colón estuvo por mucho tiempo en Portugal; a él se debe la fama universal que ha tenido este préstamo lusitano.

\section{r. Préstamos del Catalán}

El español, el portugués y el catalán constituyen las tres lenguas romances de la Península Ibérica.

El último ha tenido vicisitudes históricas especiales que lo han hecho girar en torno a la órbita del provenzal; de ahí su parecido, tenido también con el español. El catalán es una lengua puente entre el Iberorromance y el Galorromance.

Según Colón Doménech en su artículo respectivo a los "Elementos constitutivos del Español": Catalanismos (24), la palabra española 'papel' vendría del catalán "paper", invención de los chinos e introducido en Europa en el siglo X por medio de los árabes una vez que conquistaron Samarkand en 751. El paso de este importantísimo material para la difusión de la cultura se hizo en Europa por intermedio de España.

El mismo autor es de la opinión que la voz española 'entremés', 'entretenimiento' teatral (s. XV), sea debida al cat. "entremés".

Más veces, según Doménech de origen catalán: balance, 'clavel', 'revolución', 'tarifa', etc. La lista de catalanismos en el idioma español es bastante grande, según el mencionado filólogo catalán.

\section{q. Préstamos del Amerindio o Ame- ricanismos}

Con la conquista y colonización

del Nuevo Mundo los españoles se encontraron con una cantidad de objetos, costumbres, flora y fauna nuevos, propios del continente americano y desconocidos para ellos. Como sucedió y sucede en estos casos, el idioma receptor no posee ninguna termi- nología para objetos que le son desconocidos.

Dice Hockett: "Hay otra razón muy obvia para el préstamo: la de llenar un vacío en el idiolecto prestatario", y continúa: "Fácil es imaginarse una carabela española surcando las aguas del Caribe en los años del Descubrimiento. Se desencadena una tormenta; el agua cae como cataratas; el viento, rugiendo enfurecido en los mástiles y arremolinando las velas, destroza los frágiles palos de la embarcación. Restablecida la calma, los marineros no pueden menos que admitir que lo que han visto excede todas sus experiencias previas y necesitan un nombre especial; adoptan, por lo tanto, el nombre taíno": "HURACAN" (25).

Los préstamos americanos son muy conocidos en nuestro medio, razón por la cual no tomo en consideración más ejemplos. Tampoco lo voy hacer con los préstamos debidos a formas dialectales; más bien quiero inistir en los préstamos que ha recibido el idioma inglés del francés y del escandinavo, aunque esta parte se aparte bastante de los propósitos de este trabajo, y demostrar muy someramente cómo el inglés tampoco es un idioma "puro" habiendo recibido aportaciones de otros idiomas. Los "puristas" del idioma español observan con cierto recelo cómo el español, sobre todo el hispanoamericano está siendo invadido constantemente por el inglés; la historia se repite, pues también este idioma durante su historia

ha sido invadido por el francés y otros idiomas, incluido el mismo latín. He aquí algunos pocos ejemplos tomados de W.P. Lehmann, Introducción a la lingüistica histórica (26).

\section{PRESTAMOS AL INGLES}

\section{a. del Escandinavo}

Son contactos del siglo IX al XI; luego perdió la supremacía el escandinavo pero dejó notables huellas en el inglés cotidiano y no de la cultura superior.

Tanto en relación del franconormando como del escandinavo simplemente se impuso la lengua con mayor número de hablantes.

He aquí los ejemplos:

"Gift", 'regalo', "husband" 'marido', 
"sky" 'cielo', "happy" 'feliz', "same” 'mismo' "got”, 'adquirir' "want” 'desear'. "take" 'tomar', "window" 'ventana', etc.

\section{b. Del francés}

Con relación a los galicismos del inglés, la gente de mediana cultura sabe que toda o casi toda la terminología deportiva es de origen inglés, y sin embargo, la misma palabra "sport" la tomó el inglés del francés "deport" que a su vez la tomó del latín "deportare". En latín "deportare" significa 'trasladar', 'transportar', pasando quizá por 'distraer la mente'. En español antiguo 'deportarse' significa 'divertirse', 'descansar'.

Las siguientes son palabras inglesas tomadas del francés poco tiempo después del año 1066 cuando Inglaterra fue conquistada por los franconormandos ya completamente romanizados, aunque tanto los francos como los normandos eran germanos.

El franconormando fue después desalojado por el inglés, pero éste no dejó de aceptar palabras franconormandas de origen culto de frecuente uso entre la clase dominante:

\section{Gobierno y administración}

"council" "ayuntamiento', "country" 'país', "crown" "corona', "government" 'gobierno', "minister" 'ministro', "nation" 'nación' "Parliament" 'parlamento', "people" 'pueblo', “state" 'estado', etc.

\section{Títulos honoríficos}

"prince" 'príncipe', “duke" 'duque', "marquis" 'marqués', "viscount" 'visconde', "baron” 'barón', etc.

\section{Milicia}

"war" 'guerra', “army” ‘ejército', "siege" 'sitio', "armor" 'coraza', "banner" 'bandera', 'insignia', 'navy" 'armada', 'marina de guerra', etc.

\section{Términos legales}

"court" 'tribunal', "judge” 'juez', "justice" 'justicia', "crime" "crimen', 'delito', "defendant" 'acusado', "jury” 'jurado', "plaintiff" 'demandante', etc.

Las palabras anteriores inglesas de procedencia francesa son en francés latinas o germánicas.

\section{CONCLUSION}

Después de haber presentado de un modo somero unas cuantas voces tomadas como préstamos por el español, nos invade el pesimismo y nos preguntamos qué sea lo auténticamente español, esto es, no préstamo nues de esto depende su pureza. He aquí el consuelo: casi todos los préstamos anteriormente enumerados, y algunos hasta explicados, son ya españoles por su aspecto y porque así los sentimos, poco importa la proveniencia; en sus orígenes casi no existe ningún idioma autóctono en un ciento por ciento.

Las lenguas muestran una magnífica capacidad de intercambio internacional constituyendo un buen ejemplo de universalismo por encima de los egoísmos nacionales y de las ideologías políticas y religiosas que no tengan miras. El "hombre" es el que importa y no las ideologías efímeras. El es universal. Las lenguas dejan ver que el ser humano no es capaz de vivir únicamente con su país e idioma, satisfecho con ambos; necesitamos intercambiar nuestras experiencias y productos tanto en el campo material como en el espiritual.

Como lo hice ver con el latín y el inglés, el español no es la única lengua que ha recibido, recibe y recibirá influencias extranjeras. También él ha sido fuente de aportaciones extranjeras en favor de otros idiomas; las lenguas romances lo pueden demostrar.

No debemos considerarnos víctimas de los anglicismos. La culpa es únicamente nuestra.

Sólo con una cultura bien cimentada a base de mucha lectura y comentario de nuestros grandes escritores en lengua española y con una recta educación lingüística, la cual no deberá excluir de ningún modo el aprendizaje de las lenguas extranjeras tanto clásicas como modernas, sobre todo del latín y del inglés y obligando verdaderamente a nuestros estudiantes de escuela primaria y secundaria al estudio científico de nuestra gramática española, de no aludirla por difícil y monótona y aconsejando el empleo constante de un óptimo diccionario normativo, se logrará una mayor "pureza" de nuestro idioma y una mayor inteligencia en el uso de los préstamos extranjeros. 
Legislar en este asunto con leyes coercitivas contra el uso de los anglicismos o poner multas como castigo, no conducirán a nada y es hasta ridículo, pues el fenómeno no es de tipo legal o económico sino más bien de carácter CULTURAL Y EDUCATIVO.

Por eso es a la escuela, en su más amplio sentido, a la que le toca hacerle frente a este problema y no a la Asamblea Legislativa, especializada en nuestros días en sólo buscar dinero a base de impuestos. Pero en cuanto a la primera, sabemos bien cómo cada día retrocede en nuestro país desde el punto de vista académico. ¿Qué nos queda entonces? .
1. LEONARD BLOOMFIELD, Language Ed. Holt, Rinehart and Winston, New York, 1963, p.444.

2. E1 primer significado de "egregius" (de "ex" "gregis") es 'sacado de la grey', de ahí "agregio'; "rivalis", de "rivus" 'arroyo", es el que "compartía con alguno un arroyo para el riego"; "versus" significaba 'surco' y de aquí 'línea de escritura', luego 'verso'; "putare" tenía su acepción primera que era 'podar', de ahí, 'pensar', 'creer'.

3. Filosofía, poesía, música y escuela.

4. SAN AGUSTIN, De doctrina christiana, 2.13.19; cf. L.R. PALMER, The Latin Language, ed. Faber and Faber, London, 1974, p.190.

5. W.E. ELCOCK, The Romance language, ed. Faber and Faber, London, 1960, p.19.

6. ROHLFS GERHARD, Romanische Philologie T.I. ed. Winter, Heidelberg.

7. SAUSSURE FERDINAND DE, Curso de lingüistica general ed. Losada Buenos Aires, 1973, p.327.

8. LEONARD BLOOMFIELD, op. cit. p.445.

9. LEONARD BLOMMFIELD, op. cit. p.444.

10. LEHMANN WINFRED P., Introduccón a la lingüistica histórica, Ed. Gredos, Madrid, 1969, pág. 287.

11. SAPIR E., El lenguaje ed. Fondo de Cultura Económica, México, 1971, p.219.

12. LEHMANN WINFRED P., Introducción a la lingüistica histórica, Ed. Gredos, Madrid, 1969 , pág. 275 .

13. La traducción es: 'Préstamos', 'Extranjerismos', 'Préstamos de necesidad' y 'Préstamos de moda'.
14. SUETONIO Aug. 97; cf. TAGLIAVINI CARLO Origenes de las lenguas neolatinas, ed. FEC., México, 1973, p.166.

15. COROMINAS J., Diccionario crítico etimológico de la lengua castellana; cf. CUERVO, Dicc. II, 48-50, ed. Gredos, Madrid, 1954, V.I., p.612.

16. IORGU IORDAN Y MARIA MANOLIU, Manual de lingüistica románica, ed. Gredos, Madrid, 1972, V.II., pág.106.

17. Ejemplo tomado de: ULLMAN STEPHEN, Semántica, ed. Aguilar, Madrid, 1972, p.187.

18. COROMINAS J., op. cit. p.649.

19. Ejemplos tomados de: LAPESA RAFAEL. Historia de la lengua española, ed. Escelicer, Madrid, 1968, p.87.

20. LAPESA RAFAEL, op. cit. p. 88,89 .

Op. cit. p.383, ver también la nota.

22. Op. cit. p.424 a 426 .

23. R. MENENDEZ PIDAL, Manual de gramática histórica española, ed. Espasa-Calpe, S.A., Madrid, 1973, p.25.

24. GERMAN COLON DOMENECH, Catalanismos, en: ENCICLOPEDIA LINGUISTICA HISPANICA T. II, CSIC, Madrid, 1959, p.226.

25. HOCKETT CHARLES F., Curso de lingistica moderna, ed. EUDEBA, Buenos Aires, 1971, p.390.

26. Op. cit., 278, 280, 281 .

\section{BIBLIOGRAFIA}

1. BLOOMFIELD LEONARD, Language 
ed. Holt, Rinehart and Winston, Chicago, 1963.

2. BLOCH O. ET WARTBURG W. v., Dictionnaire Etymologique de la Langue française ed. Presses Universitaires de France, Paris, 1964.

3. COROMINAS JOAN, Breve Diccionario Etimológico de la lengua castellana, ed. Gredos, Madrid, 1967.

4. COROMINAS JOAN, Diccionario Crtitico Etimológico de la Lengua Castellana, ed. Gredos, Madrid, 1954.

5. ENCICLOPEDIA LINGUISTICA HISPANICA, V.II., ed. CSIC, Madrid, 1959.

6. ELCOCK W.D., The Romance Languages ed. Faber and Faber, London, 1960

7. ENTWISTLE W.J., The Spanish Language, ed. Faber and Faber, London, 1969.

8. HOCKETT CHARLES F., Curso de Lingüistica Moderna, ed. EUDEBA, Buenos Aires, 1971.

9. IORGU IORDAN Y MARIA MANOLIU, Manual de Lingüistica Románica, Ed. Gredos, Madrid, 1972.

10. LAPESA RAFAEL, Historia de la Lengua Española, ed. Escelicer, Madrid, 1968.

11. LEHMANN WINFRED P., Introducción a la Lingüistica Histórica, ed. Gredos, Madrid, 1969.

12. LÜDTKE HELMUT, Geschichte des romanischen Wortschatzes, I. B., ed. Rombach, Freiburg i. Br., 1968.

13. MENENDEZ PIDAL RAMON, Manual de Gramática Histórica Española, ed. Espasa-Calpe, S.A., Madrid, 1973.

14. METZELTIN MICHAEL, Einführung in die hispanistische Sprachwissenschaft, ed. Niemeyer, Tübingen, 1973.

15. SAPIR EDWARD, El lenguaje ed. Fondo de Cultura Económica, México, D.F., 1971.

16. SAUSSURE FERDINAND DE, Curso de Lingüistica General, ed. Losada, S.A., Buenos Aires, 1973.

17. STOLZ FRIEDRICH, Historia de la Lengua Latina, ed. UTEHA, México, D.F., 1961.

18. STORIA DELLA LETTERATURA ITALIANA, V.I., Ed. Garzanti, 1972.

19. TAGLIAVINI CARLOS, Origenes de las Lenguas Neolatinas, FCE., México, D.F., 1973.

20. VIDOS B.E., Handbuch der Romanischen Sprachwissenschaft, Hueber Verlag, München, 1968.

21. UllmanN STEPHEN, Semántica, Introducción a la Ciencia del Significado, ed. Aguilar, Madrid, 1972.

22. VÄ̈NÄNEN VEIKKO, Introducción al Latin Vulgar, ed. Gredos, Madrid, 1971.

23. WARTBURG W. v., Evolution et Structure de la Langue Française, ed. A. Francke, S.A. Berna, 1965. 